\title{
St. George's Respiratory Questionnaire (SGRQ) sebagai Alat Bantu Diagnostik serta Prediktor Terjadinya Chronic Pulmonary Aspergillosis (CPA) pada Pasien Tuberkulosis Paru Pasca Terapi
}

\author{
William S. Wangko, ${ }^{1}$ Indra Kurniawan, ${ }^{2}$ Maarthen C. P. Wongkar, ${ }^{3}$ Agung Nugroho, ${ }^{4}$ \\ Efata B. Polii ${ }^{4}$
}

\author{
${ }^{1}$ Rumah Sakit Gereja Masehi Injili di Indonesia (GMIM) Pancaran Kasih Manado, Indonesia \\ ${ }^{2}$ Rumah Sakit Meilia, Depok, Indonesia \\ ${ }^{3}$ Rumah Sakit Umum Imanuel Sumba, Sumba Timur, Indonesia \\ ${ }^{4}$ Bagian Ilmu Penyakit Dalam Fakultas Kedokteran Universitas Sam Ratulangi - RSUP Prof. \\ Dr. R. D. Kandou, Manado, Indonesia \\ Email: william.wangko06@gmail.com
}

\begin{abstract}
Patients of post therapy lung tuberculosis (TB) that still have permanent or worsened clinical signs might be caused by chronic pulmonary aspergillosis (CPA). Diagnosis of CPA is difficult to confirmed without complete supporting tests. This study was aimed to establish whether Saint George's Respiratory Questionnaire (SGRQ) could be used as diagnostic tool and predictor of the occurence of CPA in post therapy lung TB patients. This was an analytical observational study with a cross sectional design. There were 72 patients who had negative Gene Xpert sputum; 34.7\% with positive Aspergillus-specific IgG. Their clinical signs were evaluated with SGRQ. The results showed that there was a very significant relationship between clinical score and CPA $(p<0.0001)$. The lower the clinical score the less the probability of CPA. In this analysis we determined the diagnosis value of clinical score with a probability cut-off point $=0.5$ which led to clinical score cutoff point of 45.6 with further results, as follows: sensitivity $68.0 \%$; specificity $95.7 \%$; positive predictive value $89.5 \%$; negative predictive value $84.9 \%$; OR 47.8 , and CI $95 \%(9,2-248,2)$. In conclusion, SGRQ could be used as diagnostic tool and predictor of the occurence of CPA in post therapy lung TB patients.
\end{abstract}

Keywords: post therapy lung TB; chronic pulmonary aspergillosis; Saint George's Respiratory Questionnaire (SGRQ)

\begin{abstract}
Abstrak: Pasien TB paru pasca terapi yang masih memperlihatkan gejala klinis menetap atau bahkan memberat dapat disebabkkan oleh adanya chronic pulmonary aspergillosis (CPA). Diagnosis CPA sulit ditegakkan tanpa adanya pemeriksaan penunjang yang lengkap. Penelitian ini bertujuan untuk menentukan apakah Saint George's Respiratory Questionnaire (SGRQ) dapat menjadi alat bantu diagnostik serta prediktor terjadinya CPA pada pasien TB paru pasca terapi. Jenis penelitian ialah analitik observasional dengan desain potong lintang. Hasil penelitian mendapatkan 72 pasien dengan sputum Gene Xpert negatif (34,7\% dengan positif IgG Aspergillus) dilakukan penilaian skor klinis menggunakan SGRQ. Hasil uji menunjukkan terdapat hubungan sangat bermakna antara skor klinis dengan terjadinya CPA $(\mathrm{p}<0,0001)$. Makin rendah skor klinis makin kecil peluang terjadinya CPA. Melalui analisis ini dapat ditentukan nilai diagnosis skor klinis SGRQ dengan mengambil titik potong peluang $=0,5$. Nilai peluang $=0,5$ memberikan titik potong skor klinis $=45,6$. Dengan titik potong skor klinis $\mathrm{SGRQ}=45,6$ diperoleh nilai-nilai diagnosis sebagai berikut: Sensitivitas $=68,0 \%$; Spesifisitas $=95,7 \%$; Nilai Prediksi Positif $=89,5 \%$; Nilai Prediksi Negatif $=84,9 \% ;$ OR $=47,8$ dengan CI 95\% (9,2-248,2). Simpulan penelitian ini ialah SGRQ dapat menjadi alat bantu diagnostik serta prediktor terjadinya CPA pada pasien TB paru pasca terapi.
\end{abstract}

Kata kunci: tuberkulosis paru pasca terapi; chronic pulmonary aspergillosis; Saint George's Respiratory Questionnaire (SGRQ) 


\section{PENDAHULUAN}

Tuberkulosis (TB) merupakan penyakit infeksius yang masih menjadi masalah kesehatan di seluruh dunia karena angka morbiditas dan mortalitasnya yang masih cukup tinggi. Insiden kasus TB meningkat dari 5 juta $(4,8-5,1$ juta $)$ pada tahun 1990 menjadi 7,1 juta $(6,9-7,3$ juta $)$ di tahun $2013^{1,2}$ dengan kematian akibat TB berkisar 1,3 juta di tahun 2013.1,3 Data pada tahun 2016 memperlihatkan bahwa TB ditemukan pada sekitar 10,4 juta penduduk dengan 1,3 juta kematian pada individu tanpa HIV dan 374.000 kematian pada individu terinfeksi HIV. Diperkirakan hanya sekitar 57\% dari kasus TB paru dengan konfirmasi bakterial yang dilaporkan ke WHO. ${ }^{4}$

Chronic pulmonary aspergillosis (CPA) dapat menimbulkan komplikasi serta menyerupai TB paru pasca terapi. ${ }^{4,5}$ Telah dilaporkan bahwa pasien dengan TB mempunyai defek pada makrofag, monosit, dan fungsi sel $\mathrm{T}$, serta defek pada kemotaksis sehingga lebih mudah terinfeksi jamur. ${ }^{1,3}$ Selain itu, pada TB paru yang telah sembuh masih dapat ditemukan kavitas paru. Kavitas yang terbentuk atau yang sudah ada sebelumnya dapat terinfeksi Aspergillus yang kemudian berlanjut dengan terbentuknya aspergiloma setelah infeksi berlangsung bulanan ataupun tahunan. Pada sebagian pasien TB paru pasca terapi masih didapatkan gejala klinis berupa batuk, sesak napas, hemoptoe yang menetap atau bahkan memberat. ${ }^{6,7}$ Adanya infeksi CPA seringkali tidak disadari oleh para klinisi. Di antara banyak penyebab yang mendasarinya, TB merupakan penye-bab dasar utama yang umum dalam perkembangan CPA., ${ }^{1,8-10}$

Pada tahun 1960 Research Committee of the British Thoracic and Tuberculosis Association memperkirakan prevalensi CPA pada pasien dengan kavitas residual setidaknya $2,5 \mathrm{~cm}$ pada foto toraks setelah terapi TB. Penelitian tersebut melibatkan lebih dari 500 pasien dari 55 Chest Clinics dengan dua kali pemeriksaan yaitu 12 bulan setelah sputum Mycobacterium tuberculosis (basil tahan asam/BTA) negatif dan setelah 3 tahun. Sebesar 25\% pasien terdeteksi adanya Aspergillus precipitins dalam darah.
Baik precipitins serta gambaran radiologis aspergiloma terdeteksi sebesar $14 \%$ pada 12 bulan dan 22\% sekitar 3-4 tahun. ${ }^{10}$

Secara ekologi Aspergillus dan $M$. tuberculosis saling berhubungan karena Aspergilllus mendapatkan keuntungan dari kerusakan jaringan paru yang diakibatkan oleh bakteri tersebut. ${ }^{11}$ Rodriguez et $\mathrm{al}^{11}$ melaporkan adanya hubungan antara tingkat antibodi IgG Aspergillus dan kavitas.

Aspergillosis adalah infeksi jamur yang diakibatkan oleh karena infeksi atau alergi terhadap jamur genus Aspergillus. Di antara sekian banyak spesies Aspergillus, A. fumigatus merupakan spesies yang paling umum menyebabkan aspergillosis. Aspergilosis paru adalah entitas klinis umum termasuk CPA (single pulmonary aspergilloma), allergic bronchopulmonary aspergillosis, subacute invasive (chronic necrotizing pulmonary), dan acute invasive aspergillosis. ${ }^{1,2,11-13}$ CPA memperlihatkan gejala klinis yang mirip dengan penyakit paru lainnya yang menyebabkan kesulitan untuk menegakkan diagnosis. Imunodefisiensi dan/atau penyakit paru yang mendasari merupakan faktor utama yang mendahului aspergillosis. Faktor risiko lainnya ialah defek genetik. Defisiensi surfaktan A2 dan toll-like receptor 4 dapat mengubah fungsi imun dasar. Pasien dengan CPA memperlihatkan profil produksi sitokin yang khas Th2 dan produksi gamma interferon yang berkurang atau tidak ada sama sekali. ${ }^{10}$

Diagnosis CPA merupakan hal yang sulit tanpa adanya pemeriksaan penunjang yang lengkap, dikarenakan CPA dan TB paru memberikan gejala klinis serupa. ${ }^{14-17}$ Kultur sputum negatif sering ditemukan pada CPA. ${ }^{17}$ Baku emas untuk menegakkan diagnosis adanya CPA ialah pemeriksaan IgG Aspergillus. Pemeriksan ini cukup mahal dan ketersediaanya di laboratorium serta fasilitas kesehatan lainnya masih sangat terbatas terutama di daerah dengan prevalensi TB paru yang tinggi. ${ }^{9,15}$ Ketepatan diagnosis CPA sangat dibutuhkan karena CPA yang diterapi masih memberikan angka kematian yang cukup tinggi, yaitu 20$30 \%$ untuk jangka pendek, dan 50\% untuk jangka waktu 5 tahun. ${ }^{10}$ 
Deteksi kadar IgG yang tinggi terhadap Aspergillus dapat membantu membedakan CPA dari kolonisasi atau penyakit infeksi lainnya. Umumnya commercial kits untuk deteksi IgG Aspergillus memperlihatkan spesifisitas dan sensitivitas di atas $80 \%$. Walaupun demikian pasien dengan penyakit paru kronis atau bentuk kronis lainnya dari Aspergillosis seperti allergic bronchopulmonary aspergillosis dapat juga meningkatkan kadar IgG Aspergillus sehingga dideteksi sebagai kasus positif palsu. ${ }^{11}$

Saint George's Respiratory Questionnaire (SGRQ) ialah kuesioner yang dirancang untuk menilai status kesehatan pada kasus penyakit saluran napas. Penggunaan kuesioner ini telah dievaluasi pada berbagai penyakit saluran napas termasuk penyakit paru obstruktif kronis (PPOK). ${ }^{18}$ Sampai saat ini belum ada publikasi untuk menilai apakah skor klinis SGRQ dapat menjadi alat bantu diagnostik serta prediktor terjadinya CPA. ${ }^{2,6,18}$

Penelitian ini bertujuan untuk mengetahui apakah SGRQ dapat menjadi alat bantu diagnostik serta prediktor terjadinya CPA pada pasien TB paru pasca terapi yang tentunya akan sangat bermanfaat bagi para klinisi yang menangani pasien TB paru pasca terapi dengan kecurigaan terinfeksi CPA sedini mungkin, terlebih lagi bila tidak tersedia pemeriksaan penunjang yang menjadi baku emas di fasilitas kesehatan.

\section{METODE PENELITIAN}

Penelitian ini dilakukan di Poliklinik Paru dan Ruang Rawat Paru Irina C5 RSUP Prof. Dr. R. D. Kandou Manado sejak bulan Oktober 2017 sampai Januari 2018. Jenis penelitian ialah analitik observasional dengan desain potong lintang. Kriteria inklusi ialah pasien TB paru pasca Obat Anti Tuberkulosis (OAT) lengkap yang masih simtomatik selama lebih dari 3 bulan dengan hasil sputum Gene Xpert negatif. Kriteria eksklusi ialah pasien dengan imunokompromais (infeksi HIV/AIDS, leukemia, keganasan, transplantasi), dan yang telah mendapat pengobatan anti jamur sistemik sebelumnya, terapi kortikosteroid lebih dari $10 \mathrm{mg}$ setara prednison per hari selama lebih dari 3 minggu dalam 6 bulan terakhir, dan terapi imunosupresan.

Pada pasien yang terlibat dalam penelitian ini dilakukan penilaian skor klinis menggunakan SGRQ. Diagnosis CPA berdasarkan pada adanya gejala klinis atau abnormalitas radiologik selama minimal tiga bulan, dengan bukti IgG Aspergillus positif. Analisis data yang digunakan ialah analisis regresi logistik.

\section{HASIL PENELITIAN}

Penelitian ini dilaksanakan di Poliklinik Paru dan Ruang Rawat Paru Irina C5 RSUP Prof. Dr. R. D. Kandou Manado sejak bulan Oktober 2017 sampai Januari 2018. Dari 72 pasien yang ikut dalam penelitian ini, terdapat 37 orang $(51,4 \%)$ laki-laki dan 35 orang $(48,6 \%)$ perempuan. Tabel 1 memperlihatkan karakteristik sampel penelitian berdasarkan usia, berat badan, dan tinggi badan. Dari 72 sampel pasien TB paru pasca terapi terdapat 25 orang $(34,7 \%)$ dengan infeksi CPA (IgG Aspergillus positif) dan 47 orang $(65,3 \%)$ tidak terinfeksi CPA (IgG Aspergillus negatif). Gambaran radiologik dinilai dengan adanya kavitas pada foto polos dada. Dari 72 pasien TB paru pasca terapi, pada 60 pasien $(83,3 \%)$ ditemukan kavitas, sedangkan pada 12 pasien $(16,7 \%)$ tidak terdapat kavitas.

Hubungan antara skor klinis SGRQ dan CPA diuji dengan analisis koefisien korelasi Point Biserial sebab variabel CPA merupakan variabel kategori dikotomi. Hasil analisis ini memperoleh $\mathrm{r}_{\mathrm{pb}}=0,622$ dengan nilai $\mathrm{p}<0,0001$ yang menyatakan terdapat hubungan yang cukup kuat dan bermakna antara skor klinis SGRQ dan CPA (Gambar 1).

Hubungan antara skor klinis SGRQ dengan kejadian CPA dianalisis dengan analisis regresi logistik yang menunjukkan terdapat hubungan yang sangat bermakna antara skor klinis dengan terjadinya CPA ( $<<0,0001)$. Makin rendah skor klinis makin kecil peluang terjadi CPA. Dengan demikian, skor klinis dapat dijadikan prediktor terhadap kejadian CPA. Hal ini berarti setiap skor klinis SGRQ dapat diprediksi besarnya peluang terjadi CPA. Oleh sebab itu, melalui analisis ini dapat ditentukan nilai diagnosis 
dari skor klinis SGRQ dengan mengambil titik potong peluang $=0,5$. Nilai peluang $=0,5$ akan memberikan titik potong skor klinis $\mathrm{SGRQ}=(7,669 / 0,168)=45,6$. Dengan titik potong skor klinis SGRQ $=45,6$ maka diperoleh nilai-nilai diagnostik sebagai berikut: Nilai Sensitivitas $=68,0 \%$; Nilai Spesifisitas $=95,7 \%$; Nilai Prediksi Positif (NPP) $=89,5 \%$; Nilai Prediksi Negatif $(\mathrm{NPN})=84,9 \% ;$ Odds Ratio $(\mathrm{OR})=$ 47,8 dengan Confidence Interval (CI) 95\% $(9,2$ - 248,2) (Tabel 2 dan 3).

Tabel 1. Karakteristik sampel penelitian berdasarkan usia, berat badan, dan tinggi badan, serta infeksi CPA dan gambaran radiologis

\begin{tabular}{lccccc}
\hline Variabel & N & Min & Maks & Rerata & Persentase \\
\hline Usia (tahun) & 72 & 30 & 84 & 56,07 & \\
Berat badan (kg) & 72 & 23 & 70 & 43,8 & \\
Tinggi badan (cm) & 72 & 137 & 176 & 158,9 & \\
CPA* & & & & & \\
$\quad$ Positif & 25 & & & & 34,7 \\
$\quad$ Negatif & 47 & & & & 65,3 \\
$\quad$ Total & 72 & & & & 100 \\
Kavitas** & & & & & \\
$\quad$ Positif & 60 & & & & 16,3 \\
$\quad$ Negatif & 12 & & & & \\
$\quad$ Total & 72 & & & & \\
\hline
\end{tabular}

$\mathrm{N}=$ jumlah sampel penelitian; Min = minimum; Maks = maksimum

*Pemeriksaan ELISA; **Pemeriksaan radiologis

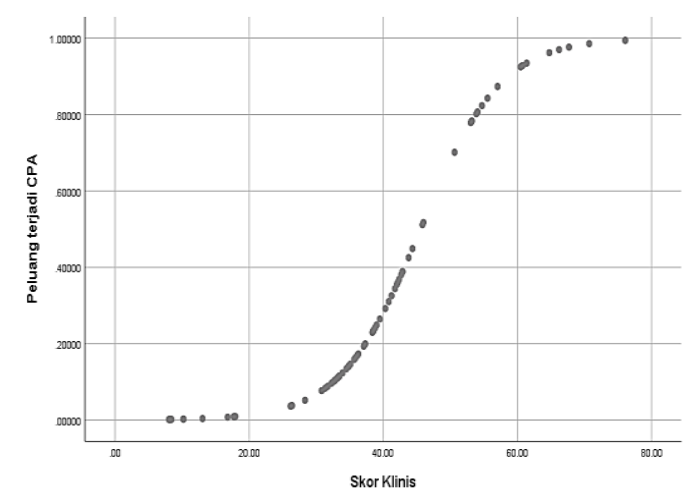

Gambar 1. Scatterplot hubungan skor klinis SGRQ dengan peluang terjadinya CPA

Tabel 2. Titik potong skor klinis SGRQ dan CPA

\begin{tabular}{lllccc}
\hline \multicolumn{2}{l}{ Skor Klinis SGRQ } & & CPA Positif & CPA Negatif & Total \\
\hline Titik potong & $\geq 45,6$ & Jumlah (N) & 17 & 2 & 19 \\
skor klinis & & Skor Klinis \% & $89,5 \%$ & $10,5 \%$ & $100 \%$ \\
& CPA \% & $68,0 \%$ & $4,3 \%$ & $26,4 \%$ \\
Titik potong & $<45,6$ & Jumlah (N) & 8 & 45 & 53 \\
Skor Klinis & & Skor Klinis \% & $15,1 \%$ & $84,9 \%$ & $100 \%$ \\
& CPA \% & $32,0 \%$ & $95,7 \%$ & $73,6 \%$ \\
\multirow{2}{*}{ Total } & Jumlah (N) & 25 & 47 & 72 \\
& Skor Klinis \% & $34,7 \%$ & $65,3 \%$ & $100 \%$ \\
& CPA \% & $100 \%$ & $100 \%$ & $100 \%$ \\
\hline
\end{tabular}


Tabel 3. Estimasi risiko

\begin{tabular}{lccc}
\hline & & \multicolumn{2}{c}{ 95\% Confidence Interval } \\
\cline { 3 - 4 } & Value & Lower & Upper \\
\hline OR skor klinis (positif/negatif) & 47,813 & 9,211 & 248,186 \\
Jumlah (N) & 72 & & \\
\hline
\end{tabular}

\section{BAHASAN}

Pada penelitian ini didapatkan 72 pasien terdiri dari 37 orang $(51,4 \%)$ lakilaki dan 35 orang $(48,6 \%)$ perempuan dengan usia berkisar antara 30 dan 84 tahun (rerata 56,07 tahun). Hasil penelitian ini selaras dengan penelitian Rodriguez et $\mathrm{al}^{11}$ di Kuba yang melaporkan bahwa CPA lebih sering ditemukan pada usia pertengahan dan terdapat sedikit perbedaan antara kedua jenis kelamin, predominan pada laki-laki. Umumnya penyakit ini dimulai pada usia 50 tahun. Hal ini mungkin disebabkan karena proses penuaan yang memengaruhi anatomi paru, degenerasi parenkim paru dan jaringan elastin sekitar duktus alveolaris sehingga terjadi ekspansi ruang udara dan berkurangnya jaringan ikat paru. ${ }^{11}$

Laporan World Health Organization (WHO) tahun 2015 menyatakan bahwa sebagian besar TB klinis dan abnormalitas radiologik atau hasil histologik yang berhubungan dengan TB mempunyai spesifisitas yang rendah, sehingga dapat terjadi misdiagnosis $\mathrm{TB}$, dan berakibat pasien mendapatkan pengobatan TB yang sebenarnya tidak diperlukan. ${ }^{19}$ Walaupun demikian, prevalensi CPA pada kasus pasca terapi TB dan kontribusi misdiagnosis CPA sebagai TB masih tidak jelas. ${ }^{4}$

Dalam menegakkan diagnosis penyakit paru sering diabaikan adanya infeksi fungal terutama CPA oleh karena pemeriksaan penunjang yang sesuai tidak dilakukan/ tersedia. Para klinisi harus waspada terhadap adanya gambaran radiologis paru berawan dan gejala klinis penyakit ini dan harus didukung dengan uji mikrobiologi terutama deteksi antibodi IgG Aspergillus bila tersedia. Bila pemeriksaan tersebut tidak dilakukan maka pasien sering didiagnosis sebagai TB paru dengan hasil sputum negatif, fibrosis lobus superior yang progresif, atau TB paru rekuren; kesemuanya akan berdampak pada pengobatan yang tidak sesuai. ${ }^{10}$ Menurut WHO, prevalensi CPA pada pasien TB paru yang diterapi dan adanya kontribusi diagnosis CPA yang keliru pada prevalensi TB masih tidak jelas. ${ }^{20}$

Pemeriksaan sputum untuk Aspergillus pada CPA sering negatif. Page et $\mathrm{al}^{17}$ meneliti kejadian CPA pada TB paru pasca terapi dengan kavitas di Uganda dan melaporkan kejadian CPA pada pasien yang resurvei sebesar $4,9 \%$. Kombinasi peningkatan IgG Aspergillus, batuk kronis atau hemoptisis, dan kavitas pada foto toraks memperlihatkan sensitivitas $87,5 \%$ dan spesifisitas 99,6\% untuk diagnosis CPA.

Pada penelitian ini digunakan baku emas IgG Aspergillus fumigatus positif untuk menegakkan diagnosis CPA. Menurut Denning et $\mathrm{al}^{7}$ dan panduan tatalaksana CPA Infectious Disease Society of America (IDSA) dan European Respiratory Society (ERS) deteksi IgG Aspergillus merupakan modalitas utama dan kunci diagnosis untuk pasien yang dicurigai terinfeksi CPA. ${ }^{7,14}$ Adanya IgG Aspergillus dapat membedakan antara pasien yang terinfeksi dan kolonisasi Aspergillus dengan nilai prediksi positif $100 \%$ untuk mendeteksi infeksi. ${ }^{4,9}$

Hasil uji statistik menunjukkan terdapat hubungan yang sangat bermakna antara skor klinis SGRQ dengan terjadinya CPA $(p<0,0001)$. Hasil ini menyatakan makin rendah skor klinis SGRQ makin kecil peluang terjadinya CPA. Dengan demikian, skor klinis SGRQ dapat dijadikan prediktor terhadap kejadian CPA. Melalui analisis ini dapat ditentukan nilai diagnosis dari skor klinis dengan mengambil titik potong peluang $=0,5$. Nilai peluang $=0,5$ memberikan titik potong skor klinis $=45,6$. Dengan titik potong skor klinis $=45,6$ maka diperoleh nilai-nilai diagnosis sebagai berikut: Nilai Sensitivitas $=68,0 \%$; Nilai Spesifisitas $=$ 95,7\%; Nilai Prediksi Positif (NPP) $=89,5 \%$; 
Nilai Prediksi Negatif $(\mathrm{NPN})=84,9 \%$; OR $=$ 47,8 dengan CI 95\% (9,2-248,2). Dengan demikian SGRQ dapat digunakan sebagai alat bantu diagnostik serta prediktor terjadinya CPA secara dini pada pasien TB paru pasca terapi agar dapat menekan angka morbiditas dan mortalitas pasien dengan CPA lanjut terutama di daerah prevalensi TB yang masih tinggi.

\section{SIMPULAN}

SGRQ dapat menjadi alat bantu diagnostik serta prediktor terjadinya CPA pada pasien TB paru pasca terapi.

Kejadian global dari CPA sebagai sekuel dari TB paru cukup tinggi dan memerlukan penelitian lanjut. Diharapkan bahwa identifikasi CPA yang tepat dapat memodifikasi status kesehatan nasional dalam hal tuberkulosis dan penyakit lainnya dan memperbaiki harapan hidup dan menyelamatkan pasien dari kesalahan diagnosis.

\section{Konflik Kepentingan}

Penulis menyatakan tidak terdapat konflik kepentingan dalam studi ini.

\section{DAFTAR PUSTAKA}

1. Hedayati MT, Azimi Y, Droudinia A, Mousavi B, Khalilian A, Hedayati N, et al. Prevalence of chronic pulmonary aspergillosis in patients with tuberculosis from Iran. Eur J Clin Microbiol Infect Dis. 2015;34:1759-65.

2. Kurniawan I, Nugroho A, Wongkar MCP. Perbedaan kkor klinis, radiologis, dan fungsi paru sebagai prediktor chronic pulmonary aspergillosis pada pasien tuberkulosis paru pasca terapi [Tesis]. Manado: Universitas Sam Ratulangi; 2018.

3. Adnan, Perwitasari DA, Mulyani UA. Reliability and validity of St George Respiratory Questionnaire (SGRQ) into Indonesian Version. IJPHS. 2014;3(3):179-84.

4. Page ID, Byanyima R, Hosmane S, Onyachi N, Opira C, Richardson M, et al. Chronic pulmonary aspergillosis commonly complicated treated pulmonary tuberculosis with residual cavitation. Eur Respir J. 2019;53:1801184.

5. Denning DW, Page ID, Chakaya J, Jabeen K,
Jude CM, Cornet M, et al. Case definition of chronic pulmonary aspergillosis in resource-constrained setting. Emerging Infectious Diseases. 2018; 24(8):e1-e13.

6. Al Shair K, Atherton GTW, Kennedy D, Powell G, Denning DW, Caress A. Validity and reliability of the St. George's Respiratory Questionnaire in assessing health status in patients with chronic pulmonary aspergillosis. Chest. 2013;144(2): 623-31.

7. Denning DW, Cadranel J, Beigelman-Aubry C, Ader F, Chakrabarti A, Blot S, et al. Chronic pulmonary aspergillosis: rationale and clinical guidelines for diagnosis and management. Eur Respir J. 2016; 47(1):45-68.

8. Godet C, Philippe B, Laurent F, Cadranel J. Chronic pulmonary aspergillosis: an update on diagnosis and treatment. Respiration. 2014;88:162-74.

9. Schweer KE, Bangard C, Hekmat K, Cornely OA. Chronic pulmonary aspergillosis. Mycoses. 2014;57:257-70.

10. Denning DW, Pleuvry A, Cole DC. Global burden of chronic pulmonary aspergillosis as a sequel to pulmonary tuberculosis. Bull World health Organ. 2011;89:864-72.

11. Rodriguez NB, San Juan-Galan JL, Andreu CMF, Yera DM, Pita MB, Lancha MRP. Chronic pulmonarry aspergillosis in patients with under-lying respiratory disorders in Cuba-A pilot study. J Fungi. 2019;5(18):1-8.

12. Kousha M, Tadi R, Soubani AO. Pulmo-nary aspergillosis: a clinical review. Eur Respir Rev. 2011;20(121): 156-74.

13. Lowes D, Al-Shair K, Newton P, Morris J, Harris C, Rautemaa-Richardson R, et al. Predictors of mortality in chronic pulmonary aspergillosis. Eur Respir J. 2017;49(2):1-10.

14. Ohba H, Miwa S, Shirai M, Kanai M, Eifuku $\mathrm{T}$, Suda $\mathrm{T}$, et al. Clinical characteristics and prognosis of chronic pulmonary aspergillosis. Respiratory Medicine. 2012;106:724-9.

15. Page ID, Richardson M, Denning DW. Comparison of six Aspergillus-spesific $\mathrm{IgG}$ assays for the diagnosis of chronic pulmonary aspergillosis (CPA). Journal of Infection. 2016;72:240-9.

16. Kim SH, Kim MY, Hong SI, Jung J, Lee HJ, 
Yun SC, et al. Invasive pulmonary aspergillosis-mimicking tuberculosis. Clin Infect Dis. 2015;61:9-16.

17. Gelpi M, Argentiero J, Jones PW, Ronit A. A scoring application for the St. George's Respiratory Questionnaire. Chest. 2016; 150(3):747-8.

18. Patterson TF, Thompson GR, Denning DW, Fishman JA, Hadley S, Herbrecht R, et al. Practice guidelines for the diagnosis and management of aspergillosis: 2016
Update by the Infectious Diseases Society of America. Clin Infect Dis. 2016;64(4):e1-e60.

19. World Health Organization. 2015 Globar tuberculosis report. Geneva: WHO, 2015.

20. World Health Organization. WHO Global Tuberculosis Report. 2017. Available from: www.who.int/tb/publication/ global.report/en. Date last accesed January 8, 2018. 